\title{
Church Sponsored Child Care: Association of Regulatory Level with Quality
}

\author{
Joellen Lewsader \\ Central Michigan University
}

\author{
James Elicker
}

Purdue University

USA

\begin{abstract}
Multiple types of child care are exempt from government licensure or regulation in the United States, yet previous research has shown that stricter adherence to regulatory standards predicts higher quality programs. This study compares global child care quality and teacher-child interaction quality in churchsponsored child care centers that are legally-exempt from licensure and operate at three regulatory levels. Observations were completed in 59 church-sponsored, center-based child care programs. Centers that voluntarily followed stricter levels of regulation had higher quality. The findings have implications for policymakers and legislators who create and implement child care standards and subsidy policies.
\end{abstract}

Key words: child care quality, faith-based child care, child care regulation, teacher-child interaction

\section{Introduction}

Families should be able to trust that established institutions like government,

Correspondence regarding this article should be addressed to Joellen Lewsader, Assistant Professor, Human Development and Family Studies Office, EHS Building 415, Central Michigan University, Mount Pleasant, MI 48858. Electronic mail may be sent to lewsa1j@cmich.edu.

* A grant from the Office of Planning, Research and Evaluation, Administration for Children and Families, U.S. Department of Health and Human Services funded the collection of data for this project. Its contents are solely the responsibility of the authors and do not necessarily represent the official views of the Office of Planning, Research and Evaluation, the Administration for Children and Families, or the U.S. Department of Health and Human Services. churches, and child care centers are overseeing the provision of safe and nurturing care and education environments for young children. Yet this is not always the case, and not all child care is government-regulated in the United States. There are no unified child care quality standards across the 50 states, nor even within a single state. Currently, all of the states license most child care centers, yet there are still multiple types of licensing exemptions for programs, ranging from churchsponsored centers, to half-day preschool programs, to governmentrun centers, to those operated by a university or college (NARA \& NCCIC, 2010). 
However, we do know from previous research that programs that adhere to governmental regulations tend to be of higher quality than centers where standards are lax or few in numbers. We also know that higher quality child care leads to more positive, longer lasting outcomes for children and that there are larger quality effects for children from low-income homes.

There are approximately 11 million children under the age of 5 years in child care in the United States (NACCRRA, 2012), and a large but unknown portion of that care is completely unregulated, placing millions of young children in potentially harmful environments. Churchsponsored child care centers are an important case in the U.S., because in 12 states they are completely licenseexempt. Church-sponsored child care centers in Alabama, Arkansas, Florida, Illinois, Indiana, Louisiana, Maryland, Missouri, South Carolina, Tennessee, Utah, and Virginia (NARA \& NCCIC, 2010) may avoid government licensure by opting designation as an "unlicensed registered child care ministry." Families, in many cases, may be unaware of these regulatory differences when selecting child care. They often do not understand the important nuances in meaning among the terms regulation, licensing, and accreditation, and they assume they are all similar (Elicker, Langill, Ruprecht, \& Lewsader, 2010). These types of child care exemptions are generally not examined in research on child care quality, creating a significant gap in the research literature.

Exemption for church-sponsored child care in the U.S. is of particular importance, because approximately 80\% of Americans participate in organized religion (Kosmin \& Keysar, 2009) and state and federal governments allow churches a privileged position under the law. However, research in the U.S. that explicitly examines churchsponsored child care centers as a category is very limited. Churchsponsored child care settings, when included in research, are usually one of many types of child care programs, not specifically examined in analyses.

Churches have historically provided social services to families in the U.S., including child care (Gormley, 1995). However, over the past two decades, the U.S. Congress passed bills that shifted even more social service delivery, including child care, from national to state and local jurisdictions (Henriques, 2006; Stanziola \& Schmitz, 2003). Faith-based organizations like churches thus played a major part in this movement to privatize and localize social services. In 1996, the Personal Responsibility and Work Opportunity Reconciliation Act (PRWORA) made it possible for faith-based organizations to receive federal funding for any social services provided (Burke, Fossett \& Gais, 2003). Also the Community 
Solutions Act of 2001 encouraged faithbased organizations to play a larger role in "devolution," which involves non-profit organizations taking on roles once a responsibility of state governments (Stanziola \& Schmitz, 2003). Because church-sponsored organizations have assumed a larger and increasing role in providing child care and other formal support systems to families, it is important to examine the mechanisms and quality of these programs. This study contributes to this limited body of research by focusing on church-sponsored child care as an important example of unregulated child care, comparing sub-groups that operate at three regulatory levels.

\section{Child Care Regulatory Exemption}

Although all 50 states in the USA regulate some portion of their child care settings (NACCRRA, 2012), all states still allow some child care settings to remain unregulated, or "license-exempt." Twenty-nine states allow license-exempt centers to participate in the Child Care and Development Fund (CCDF) which provides federal funds to assist low income families in purchasing child care (NARA \& NCCIC, 2010). Sixtyseven percent of the license-exempt church-sponsored child care centers in the state of Indiana participate in the CCDF voucher program (FSSA, 2013). Similarly, a mixed-method study by the Urban Institute (Rohacek, Adams, \&
Snyder, 2008) revealed that a majority of the church-sponsored child care centers, 69\%, had at least one child enrolled who had received federally funded vouchers within the last six months (Rohacek et al., 2008).

In the state of Indiana, licenseexempt church-sponsored child care centers are called "registered child care ministries." Church-sponsored child care centers thus have the option of being state-licensed or not. Also, church-sponsored centers have an additional regulatory option, the Voluntary Certification Process (VCP). Basic health and safety standards, at somewhat higher levels than mere registration, must be met to receive VCP status. There are currently over 700 unlicensed, registered ministry child care centers in the state, and only $63(9 \%)$ of them have completed the VCP (FSSA, 2013). Both licensed child care centers and VCP registered child care ministry centers are eligible to join the state's child care Quality Rating and Improvement System (QRIS); non-VCP registered child care ministries are not eligible. QRIS's are quality improvement programs that have been launched in 40 states in the USA, to rate the quality of child care programs at several levels, providing understandable quality information to parents that will help them make decisions about where to place their children.

The differences in level of oversight among these three regulatory options 
available to church-sponsored child care centers in Indiana are dramatic. For example, mandatory rules for licensed child care centers in Indiana are listed in 60 pages of standards, including required adult-child ratios, group sizes, minimums for staff education level and number of staff training hours required per year (FSSA, 2009). Unlicensed registered child care ministry centers in the Voluntary Certification Program (VCP) have standards contained in 10 pages, including requirements for adult-child ratios and a secondary school diploma required for teachers. The VCP standards do not specify maximum group sizes or minimum caregiver age (FSSA, 2011). Finally, registered ministry child care centers that do not participate in VCP have no standards regarding adult-child ratio, group size, staff education, or caregiver age, and the standards include only a few fire safety features, no visible firearms, and absence of observable child abuse. Standards for these centers occupy only four pages.

A critical issue facing early care and education in Indiana, and probably in other states, is that unlicensed registered child care ministry centers have been increasing in number at a steady rate since the mid-1980s (Slutz, 2000). Churches may choose not to become licensed or to follow the voluntary $(\mathrm{VCP})$ rules because they are misinformed about what is required, or because they are concerned the state government will interfere with their secular early childhood curriculum (Rohacek et al., 2008). Because there are no limits on child group size and there are no mandated inspections accounting for the number of children present, it is unknown how many children attend these legally-exempt unlicensed centers, and there is no available demographic information describing the children attending. This study examines these three regulation levels permitted for church-sponsored child care centers in Indiana. The data provided will constitute the first concrete information about the child care quality of Indiana's church-sponsored centers and may also inform policy about church-sponsored centers or other types of programs that are exempt from governmental regulation in other states or countries.

\section{Stricter Regulation Leads to Higher Quality}

Research that examines the relationship between child care quality and government regulation suggests more rigorous regulations result in higher child care center quality (Phillips, Howes, \& Whitebrook, 1992; Rigby, Ryan, \& Brooks, 2007). The definition of global child care quality used in this paper is the sum of multiple characteristics of structural features, process features, and health and safety features found in child care centers that have been determined by a consensus 
of leaders in early childhood education and care or through empirical research to positively affect children's development and their daily lives.

Adult-child ratios, group size, and teacher education are important regulatable structural factors of quality in child care centers, predictive of teacher-child interaction (process) quality (Phillips et al., 1992; Phillips et al., 2000; Phillipsen et al., 1997). States that have more demanding standards for adult-child ratios, group sizes and teacher education levels have child care centers that are higher in global classroom quality (Phillips et al., 2000). In centers where there is stricter adherence to these structural standards, caregivers' interactions with children are less harsh and more sensitive than in centers with more lax adherence to state regulations (Phillips et al., 1992). Stricter state regulations for teacher education and adult-child ratios in both licensed church-sponsored centers (Phillips et al., 1992) and other types of licensed non-profit child care centers are associated with higher global quality (Rigby et al., 2007).

\section{Quality and Child Outcomes}

Previous research has linked global quality child care to positive child outcomes and school readiness, albeit inconsistently (Mashburn et al., 2008). Child care global quality has been shown to predict long-lasting effects, with the strongest and most consistent effects for children from low socioeconomic status (SES) home environments.

The National Institute of Child Health and Human Development (NICHD) Study of Early Child Care and Youth Development measured both structural and process quality characteristics in early care with a large national sample. When the children in this longitudinal study were 24 and 36 months old, researchers examined associations between child-staff ratios, group size, caregiver training, and caregiver education level in infant classrooms and preschooler outcomes (1999). The closer child care programs adhered to established quality standards typically regulated by states, the more positive were the child outcomes. Follow-up studies showed that children who attended high quality child care had higher vocabulary levels in 6th grade at age 12 years (Belsky et al., 2007) and greater cognitive skills at age 15 years, and the higher the early child care quality, the greater the long term effect size (Vandell et al., 2010).

Pinto, Pessahna, \& Aguiar (2013), in a longitudinal study of preschool aged children, reported associations between the global quality of center-based child care for preschool age children and early literacy skills. Child care quality was measured using the Environmental Rating Scales ([ERS], Harms, Clifford, \& Cryer, 2005; Harms, Clifford, \& Cryer, 2006). These authors also reported finding negative effects on children's 
language and literacy development when children attended poor global quality child care at preschool age. Again, child care global quality was more important for children from low SES homes. In a different study, quality child care was associated with increased receptive language, vocabulary, reading, and math scores for children of mothers with low education levels when the children were in formal child care settings (Geoffroy, 2010).

Many aspects of quality child care can be regulated by states, and adherence to regulation has been shown to increase global quality, ultimately leading to positive outcomes for children. Conversely, unregulated child care settings would be expected to be lower in global quality and not as beneficial for children.

\section{Church-Sponsored Child Care}

The limited existing research specifically focused on church-sponsored child care centers suggests that higher subsidies and stronger regulations would increase the quality of care for children from lower socio-economic families (Rigby et al., 2007). Church-sponsored centers have been found to have higher global quality scores than secular for-profit centers, but lower global quality scores than non-sectarian non-profit centers (Phillips et al., 1992).

In one of the few studies that examined church-sponsored child care, Sosinsky, Lord and Zigler (2007) using the NICHD Early Child Care data, evaluated the differences in global quality between nonprofit and for-profit child care centers. This analysis divided non-profit child care centers into two subsectors of non-profit church-sponsored and non-profit nonchurch-sponsored. Results indicated that non-profit church-sponsored center quality was lower than in non-profit non-church centers. Non-profit church center quality was generally found to be the same or higher than quality in for-profit centers. It is important to keep in mind some of the data in the NICHD study were collected in Virginia, a state where non-profit churchsponsored centers are license-exempt, which may be a confounding variable influencing quality scores. Had Virginia license-exempt non-profit, churchsponsored centers been separated from licensed non-profit church-sponsored centers in the other states, conclusions about quality in different types of care may have been different.

Elicker and colleagues (2005) examined child care settings used by low-income working families in four urban counties in Indiana. Some of the child care centers examined were unlicensed registered child care ministries. This was the only study to date that explicitly identified child care centers in the sample that were licenseexempt. Sixteen percent of the families sampled used an unlicensed registered ministry center as their primary child care provider. These ministries had the lowest global quality scores in relation to the licensed child care centers and Head Start programs that other families used. 
While many children attend churchsponsored child care centers in the U.S., and some studies have included licenseexempt centers, research to date has not teased out patterns of regulation, license exemption, and quality for churchsponsored child care centers. While some authors explicitly state they collected data in church-sponsored centers in states that allow license-exemption for such centers, there has not been an explicit examination of license-exempt centers included in these samples. For example, the sample for the Phillips et al. (2000) study was selected from a list of licensed and registered centers from Virginia, Massachusetts, and Georgia. As in the NICHD study (1996, 1999, 2001, 2002), this research included Virginia and data were collected in churchsponsored centers, however licenseexemption is not mentioned in the results.

In summary, the limited data available suggest that in general church-sponsored child care global quality may fall somewhere between high quality and low quality. However, until the current study, it was unknown how special regulatory exemptions offered to church-sponsored child care centers in many localities are associated with quality. Previous research suggests that some license-exempt churchsponsored providers and their supporters resist political efforts to increase regulation, fearing that government oversight will interfere with their secular curricula for children, threatening the constitutionallyguaranteed separation between church and state (Rohacek et al., 2008; Stanziola \&
Schmitz, 2003). These separation of church and state concerns are not reflected in existing governmental child care rules, however they often carry considerable weight in U.S. political debates.

The following question was asked to explore the relationships between regulation and global child care quality and teacher-child interactions churchsponsored child care centers. Does observed global child care quality and teacher-child interaction quality differ in infant classrooms and preschool classrooms across the three groups of differently-regulated centers? The three levels of government regulation examined were: 1) licensed child care centers; 2) unlicensed child care ministry centers that meet VCP standards; and 3) unlicensed child care ministry centers that meet neither state licensing rules nor the state's voluntary certification program requirements. The study was the first to examine the associations of regulatory level with child care quality in church-affiliated child care centers.

\section{Method}

This study compared the global quality of three groups of churchsponsored child care centers in the state of Indiana, USA. The groups differed by the level of state regulation followed in daily operations. The first group consisted of 19 state-licensed child care centers, the second group consisted of 
20 unlicensed registered child care ministry centers that had completed Indiana's Voluntary Certification Program (VCP) requirements, and the third group consisted of 20 unlicensed registered child care ministry, which are required to follow only minimal safety regulations. The sample size was determined by a power analysis using a .05 alpha level for a small effect size $(\mathrm{d}=.34)$. The group sizes were limited because of small existing populations of licensed, church sponsored child care centers $(\mathrm{N}=25)$ and registered child care ministries that had completed VCP $(\mathrm{N}=78)$. The total population of the third group of church-sponsored child care centers, the registered ministries that had not completed VCP, was the largest ( $\mathrm{N}=706$; FSSA, 2013).

When possible, one infant-toddler classroom and one 4-year-old classroom were observed in each child care center. A larger percentage of unlicensed registered ministry centers had infant rooms than did the licensed child care centers. Because there are no state regulations for age groupings in unlicensed registered ministry centers, the age ranges in classrooms varied considerably. Selected preschool classrooms were those that contained the greatest number of 4-year-old children. Selected infant-toddler classrooms had children under the age of 30 months. In two cases, unlicensed registered ministry centers selected in the sample had only one classroom that contained both infants and children through school-age. In these centers quality assessments for both infants and preschoolers were completed, focusing each time on the children within the target age range for the measure.

When possible both an infant-toddler classroom and a 4-year-old classroom were observed in each child care center. A larger percentage of unlicensed registered ministries had infant rooms than did the licensed child care centers. There are no state regulations for age groupings in unlicensed registered ministries, so the age range in classroom varied considerably. For the selection of preschool classrooms, the classroom was selected that contained the greatest number of 4-year-old children. Infant-toddler classrooms selected had children under the age of 30 months. In two cases, unlicensed registered ministries in the sample only had one classroom that contained both infants and children through school-age. Both of the quality measures (for infants and for preschoolers) were completed in these classrooms, focusing each time on the children with the target age for the measure.

\section{Design and Procedure}

A group comparison design was used for the study. Separate and complete lists of the three groups of church-sponsored child care providers were obtained from the Indiana Office 
Table 1. Population and Sample Sizes of the Three Groups

\begin{tabular}{c|c|c|c|c}
\hline $\begin{array}{c}\text { Regulation Level } \\
\text { of Church- } \\
\text { Sponsored Center }\end{array}$ & $\begin{array}{c}\text { Total Number of } \\
\text { Centers in the } \\
\text { State }\end{array}$ & $\begin{array}{c}\text { Number of } \\
\text { Centers Sampled }\end{array}$ & $\begin{array}{c}\text { Number of } \\
\text { Preschool } \\
\text { Classrooms } \\
\text { Observed }\end{array}$ & $\begin{array}{c}\text { Number of } \\
\text { Infant/ Toddler } \\
\text { Classrooms } \\
\text { Observed }\end{array}$ \\
\hline $\begin{array}{c}\text { Licensed Centers } \\
\text { Voluntary } \\
\text { Certification } \\
\text { Program (VCP) } \\
\text { Centers }\end{array}$ & 25 & 19 & 19 & 20 \\
$\begin{array}{c}\text { Licensed-Exempt, } \\
\text { Non-VCP Centers }\end{array}$ & 78 & 20 & 19 & 18 \\
\hline Totals & 809 & 59 & 58 & 44 \\
\hline
\end{tabular}

of Child Care. Due to the small population size of church-sponsored state-licensed child care centers, all twenty-five centers available were invited to participate. A matched sample was then constructed for the three groups, using randomization in selection when possible within the two groups of unlicensed registered ministry centers (unlicensed, registered; and unlicensed registered meeting the Voluntary Certification Program; see Table 1.) Matching and selection was completed based on information available in the state child care management database and also after consultation with consultants who worked regularly with child care centers and registered child care ministries at the state level. The matching variables used for the three groups were: level of regulation; geographic location within the state; urban or rural; currently accepting/not accepting child care assistance funding vouchers for low income families; and total child capacity (based on square footage area in the building.) When more than one unlicensed registered child care ministry center met the matching criteria for a group, random selection was employed.

Twenty out of twenty-five (80\%) of the licensed child care centers agreed to participate. After recruitment, one additional center cancelled. Therefore nineteen licensed child care centers were observed. Twenty-seven VCPqualified registered child care ministry centers were invited to participate, and twenty (74\%) agreed to a site visit and were observed. The licensed centers and VCP ministries that refused to participate stated they were too busy or overwhelmed at the time of inquiry. Sixty-five (65) registered child care ministry centers (non-VCP) that met the study criteria were invited to participate. Twenty three (35\%) refused, and twenty (31\%) were unreachable 
after multiple attempts using various phone numbers. Two of these programs at first agreed to a visit, but later cancelled; therefore ultimately twenty $(31 \%)$ of those invited agreed to participate and were observed.

A total of 102 classrooms were observed, 58 preschool rooms and 44 infant-toddler rooms. Observations of preschool classrooms, those including 4 year olds, were completed in the morning, and most observations of infant-toddler rooms were completed in the afternoons when the children were active. When a classroom included both 4 year olds and infants, observations were completed in the morning. Most preschool classrooms in child care have an extended nap period in the early afternoons, and the late afternoon preschool age programs tend to vary greatly. The morning preschool classroom schedule of activities was generally similar among programs for comparison purposes. Children in infant-toddler classrooms were likely to have more individualized care routines and thus were observable in both the morning and afternoon.

Upon completion of the classroom observations, directors were given the opportunity to receive a summary of the observation results, and directors were also given a copy of the Early Childhood Environmental Rating Scale - Revised (ECERS-R; Harms, Clifford, \& Cryer, 2005) and the Infant / Toddler Environment Rating Scale - Revised
(ITERS-R; Harms, Clifford, \& Cryer, 2006).

\section{Measures}

- Global child care quality

The Infant Toddler Environment Rating Scale-Revised (ITERS-R) was used in classrooms with children under 30 months. It has 35 items that range from a score of 1 (inadequate) to a score of 7 (excellent). The Early Childhood Environment Rating Scale (ECERS-R) was used in child care classrooms for children aged 30 months to 5 years, including43 items, also with scores ranging from 1(inadequate) to 7(excellent). Both ITERS and ECERS rating scales have seven subscales: space and furnishing, personal care routines, listening and talking, activities, interaction, program structure, and parents and staff. The ECERS-R and the ITERS- $R$ have been widely used throughout the world to measure overall child care quality in classrooms (Goelman et al., 2006). Phillipsen, Burchinal, Howes, \& Cryer (1997) found a strong associations between ECERS scores and the structural quality variables of teacher education level and teacher-child ratio. These authors also found ITERS scores were related to teacher experience, wages and classroom structure. The creators of the scales report the internal consistency of all items in total scores as .92 for the ECERS-R (Harms, Clifford, \& Cryer, 2005) and .92 for the ITERS-R (Harms, 
Clifford, \& Cryer, 2006). Findings from several studies have reported the subscales to be highly intercorrelated, so the scales may be best used for total item means to indicate one global quality score (Bisceglia, Perlman, Schaak, \& Jenkins, 2009; Cassidy, Hestenes, Hegde, Hestenes, \& Mims, 2005; Perman, Zellman, \& Le, 2004; Goelman et al., 2006). All item scores were averaged to obtain a global mean quality score for each classroom. These global scores and also the subscales were used in the analyses.

A researcher trained to reliability at Frank Porter Graham (FPG) Child Development Institute at the University of North Carolina served as the "gold standard" for inter-observer reliability. All data collectors were either FPGtrained researchers or were trained in the field, attaining reliability with the "gold standard" rater. Inter-rater reliability was calculated using both percentages of exact agreement and Cohen's kappa coefficient. The observation team completed repeated independent observations and training until a weighted kappa of at least .60 for exact agreement was attained. An agreement level of weighted kappa $=.61$ was attained for the ECERS-R between the "gold standard" rater and the author. Kappas for two additional data collectors were .82 and .80 . Interrater percent agreements within one scale point for the ECERS-R were $88 \%$, $99 \%$ and $98 \%$, respectively. A weighted kappa of .60 was attained for the ITERS-R between the "gold standard" rater and the author. The kappas between the "gold standard" rater and the other data collectors For ITERS-R were .78 and .80. Inter-rater percent agreements within one scale point for the ITERS-R were $87 \%, 99 \%$ and $93 \%$ respectively. Mid-point reliability visits were completed with each data collector and the "gold standard" rater or the author to ensure inter-rater agreement continued to exceed $80 \%$ agreement within one scale point.

\section{- Teacher-child interaction quality}

The Caregiver Interaction Scale (CIS; Arnett, 1989) was used to measure the quality of teacher-child interactions in the classroom. CIS has been widely used as an observational measure of adult-child interaction quality in child care (Goelman et al., 2006). The CIS has four subscales, including teacher positive relationships, punitiveness, permissiveness and detachment. There are a total of 23 items, each scored using a four-point scale. Inter-rater reliability for this measure was attained at a level of $80 \%$ percentage within one scale point agreement and weighted kappa coefficient of .60 or higher. The observation team did repeated independent observations and training until percent agreement within one met or exceeded $80 \%$. Reliabilities of kappa .62, .84 and .61 were attained among the data collectors. Inter-rater 
percent agreements within one scale point for the CIS were $99 \%, 100 \%$ and $99 \%$ respectively. At the mid-point of data collection, a reliability observation check using the same procedures was performed to ensure continued high inter-rater reliability of at least $80 \%$ within one percent agreement.

\section{Results}

\section{Global Quality as a Function of Regulatory} Level

Descriptive statistics for all observed quality measures are provided in Table 2. All ECERS-R and ITERS-R items were averaged to produce a global composite quality score for each classroom. In addition, sub-scale scores were averaged and reported to give a more differentiated overview of the specific differences in quality among the three groups. Separate analyses were completed using the ECERS-R and the ITERS-R. These two scale scores were not combined or averaged, because the preschool and infant classroom environments are quite distinctive. Figure 1 summarizes the three regulatory groups' mean quality scores for each ECERS-R subscale and global quality. Figure 2 summarizes the groups' mean scores for the ITERS-R

Table 2. Assessed Global Child Care Quality and Teacher-Child Interactions as a Function of Regulatory Level

\begin{tabular}{l|c|c|c|c}
\hline \multicolumn{1}{c|}{ Observational Measure } & Licensed Center & VCP & $\begin{array}{c}\text { Registered } \\
\text { Ministry }\end{array}$ & $F$ \\
\hline ECERS-R & $4.15^{\mathrm{a}}$ & $3.91^{\mathrm{a}}$ & $2.73^{\mathrm{b}}$ & $19.35^{* * *}$ \\
& $(.73)$ & $(.66)$ & $(.88)$ & \\
ITERS-R & $4.18^{\mathrm{a}}$ & $3.51^{\mathrm{a}}$ & $2.68^{\mathrm{b}}$ & $13.78^{* *}$ \\
& $(.79)$ & $(.58)$ & $(.85)$ & \\
CIS - Preschool Positive Relationships & 2.55 & 2.69 & 2.21 & 2.98 \\
& $(.69)$ & $(.65)$ & $(.53)$ & \\
Punitive & 1.60 & 1.36 & 1.89 & 2.95 \\
& $(.77)$ & $(.50)$ & $(.78)$ & \\
Permissiveness & $2.08^{\mathrm{a}}$ & $2.01^{\mathrm{ab}}$ & $2.45^{\mathrm{c}}$ & \multirow{2}{*}{$5.22^{* *}$} \\
& $(.48)$ & $(.44)$ & $(.43)$ & \\
Detachment & $1.45^{\mathrm{a}}$ & $1.36^{\mathrm{ab}}$ & $1.86^{\mathrm{c}}$ & $3.80^{*}$ \\
CIS - Infant/Toddler & $(.57)$ & $(.45)$ & $(.77)$ & \\
Positive Relationships & 2.59 & 2.61 & 2.12 & 2.01 \\
Punitive & $(.77)$ & $(.71)$ & $(.63)$ & \\
& $1.25^{\mathrm{a}}$ & $1.23^{\mathrm{ab}}$ & $1.67^{\mathrm{c}}$ & $3.51^{*}$ \\
Permissiveness & $(.31)$ & $(.46)$ & $(.72)$ & \\
& 2.03 & 2.22 & 2.35 & \multirow{2}{*}{1.65} \\
Detachment & $(.42)$ & $(.39)$ & $(.52)$ & \\
& 1.38 & 1.41 & 1.89 & 2.10 \\
\hline
\end{tabular}

Note. Standard deviations appear in parenthesis below means. Means with differing subscripts within rows are significantly different at the $\mathrm{p}<.05$ based on Bonferroni post hoc tests.

${ }^{*} p<.05 * * p<.01$ 


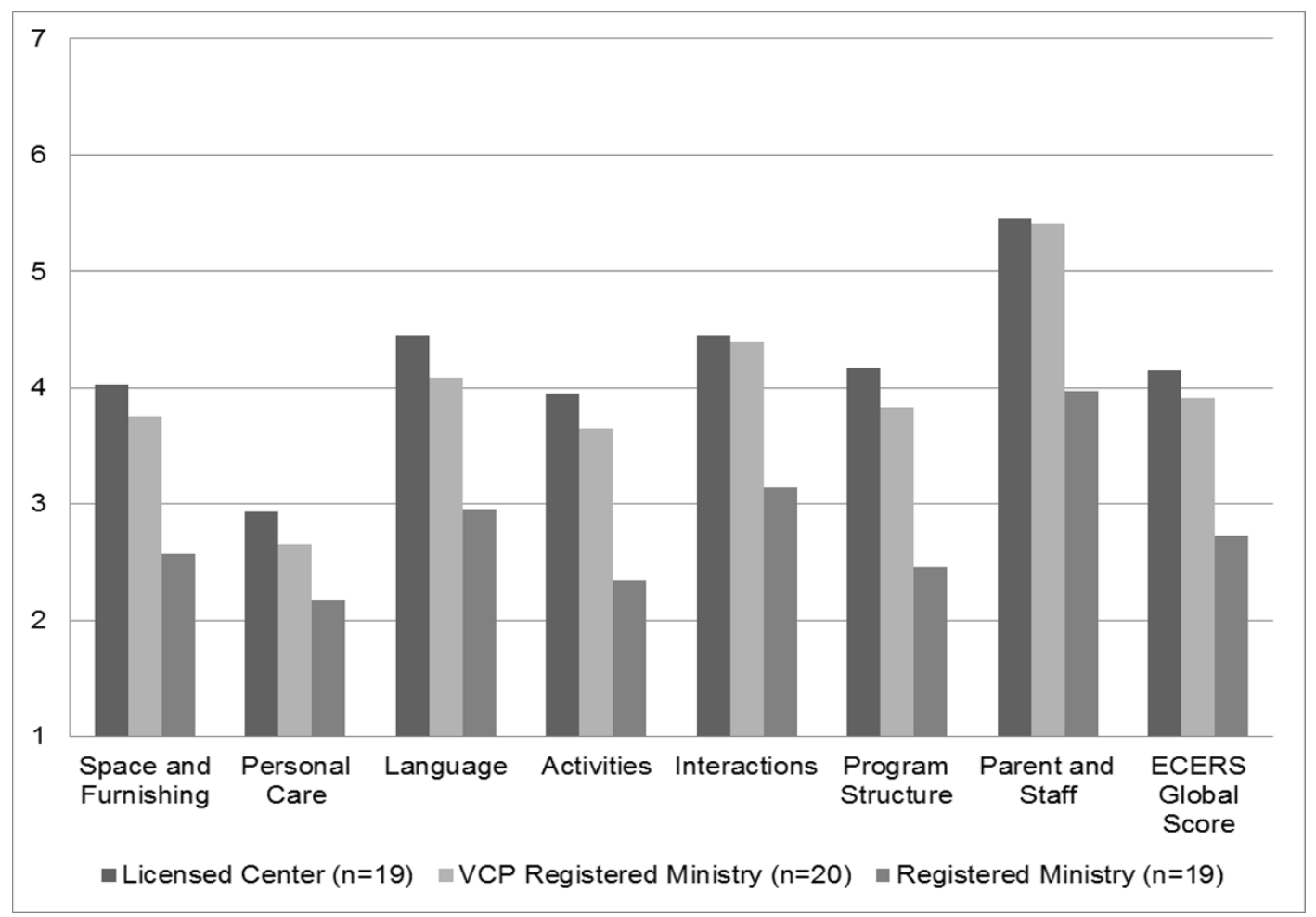

Figure 1. Mean Environmental Rating Subscale Scores for Preschool Classrooms.

subscales and global quality.

Comparison of the mean child care quality scores was made using ANOVA and Bonferroni post hoc tests. There were significant main effects for regulation level, and post hoc tests showed that global quality scores were significantly different between unlicensed registered ministry centers and both VCP registered ministry centers and licensed centers. This pattern of results was found for both preschool classrooms, $F(2,55)=19.35, p=<.001$, $\mathrm{ES}=.41$; and infant classrooms, $F(2,41)$ $=13.78, p=<.001, \mathrm{ES}=.40$. Registered ministries' preschool classrooms had significantly lower global mean child care quality scores than both VCP registered ministries' and licensed centers' preschool classrooms $(2.73$ \pm .88 versus $3.91 \pm .66$ and $4.15 \pm .73$, respectively, $p<.001$ ).

This pattern was also found in infant classrooms. There was a significant main effect for regulation level, and registered ministries had significantly lower global mean child care quality scores than VCP registered ministries and licensed centers $(2.68 \pm .85$ versus $3.51 \pm .58, p=.007$ vs. $4.18 \pm .79, p<.001)$.

Teacher-Child Interaction Quality as a Function of Regulatory Level

ANOVA comparing the three groups' mean teacher-child interaction scores in preschool classrooms revealed statistically 


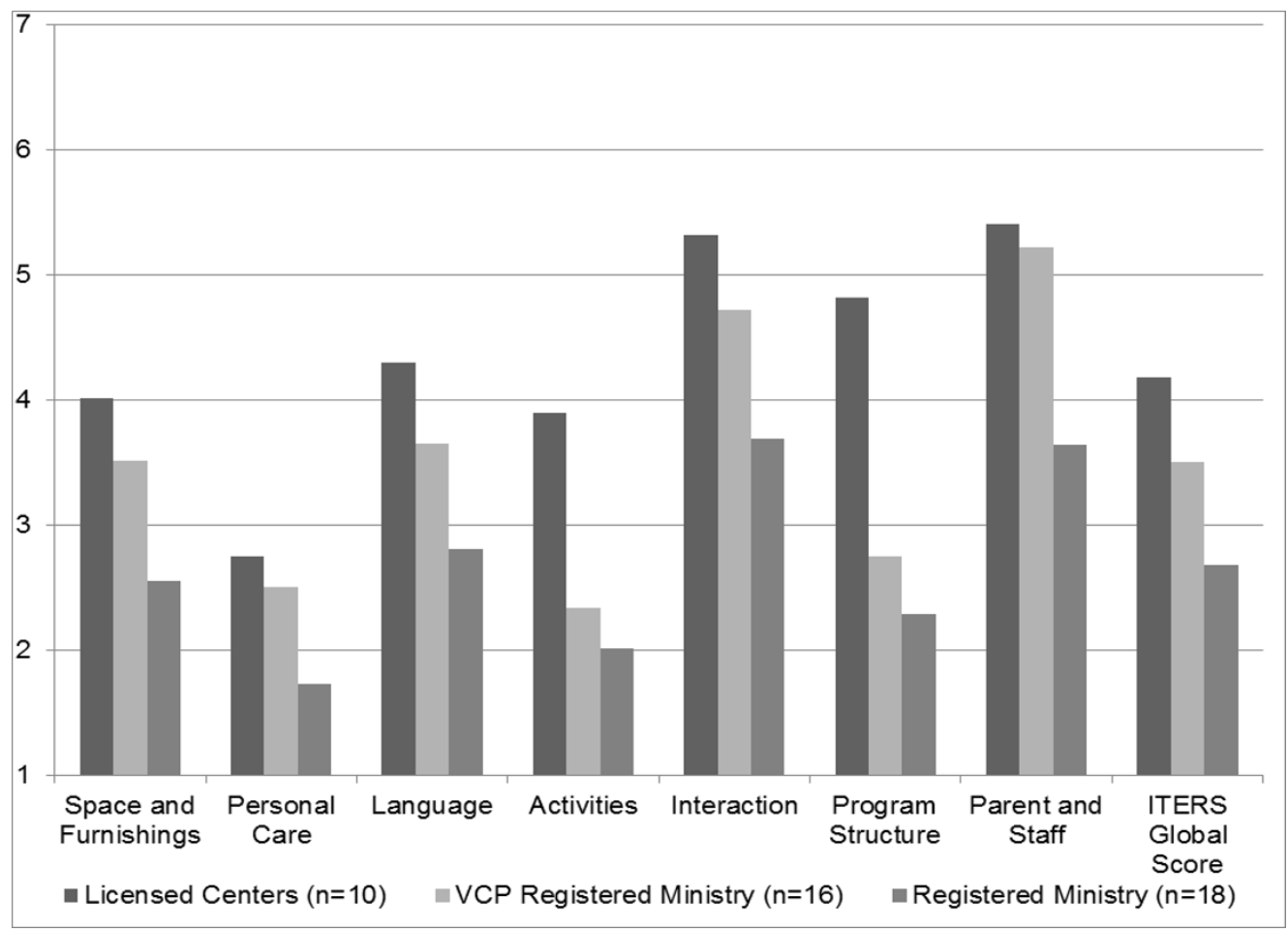

Figure 2. Mean Environmental Rating Subscale Scores for Infant-Toddler Classrooms.

significant or near-significant main effects of regulatory level for both negative and positive interaction subscales (Figure 3). There were significant main effects of regulation level for teacher permissiveness, $F(2,55)$ $=5.22, p=.008$, ES = .16; and teacher detachment, $F(2,55)=3.80, p=.02$, ES

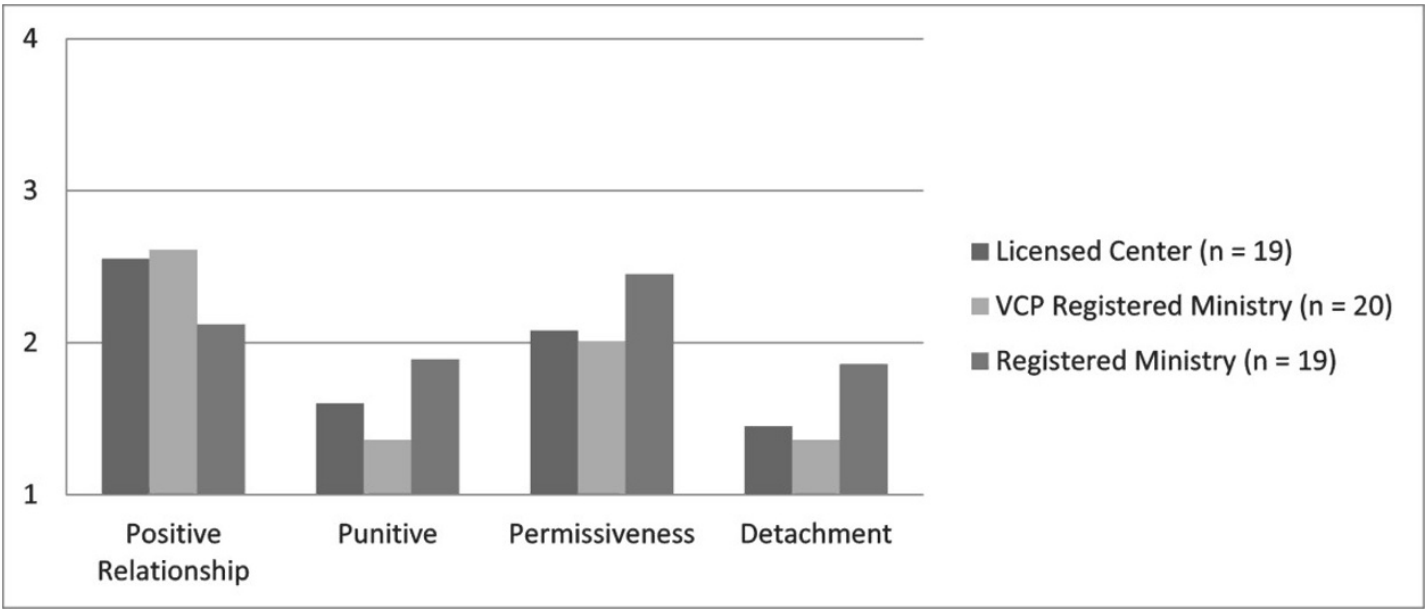

Figure 3. Mean CIS Interaction Subscale Scores in Preschool Classrooms 
$=.12$. Bonferroni post hoc test results showed teachers in licensed centers and registered ministries were significantly more permissive that teachers in VCP registered ministries $(2.08 \pm .48, p=.04$ and $2.45 \pm .43, p=.01$ versus $2.01 \pm .44$ ). Registered ministry teachers were significantly more detached than VCP registered ministries $(1.87 \pm .77$, versus $1.36 \pm .45, p=.04$ )

ANOVA comparing the teacher-child interaction scores in the infant classrooms revealed a significant main effect for regulatory level only for teacher punitiveness among the three groups, $F(2,41)=3.51, p=.04, \mathrm{ES}=.15$. The teachers in the registered ministries were more punitive than the teachers in the VCP registered ministries, (1.67 \pm .72 versus $1.23 \pm .35, p=.06$ ).

\section{Discussion}

A major contribution of this study was the deliberate exploration of quality in legally license-exempt centerbased child care. An important example in the U.S. is church-sponsored child care, because many states allow exemption from regulation for this type of center. The results show that churchsponsored center-based child care programs that follow state licensing regulations have higher global quality than center-based child care programs that are legally-exempt, not licensed, and follow only minimal state regulations. The findings of this study also show significant differences in the quality of teacher-child interactions, when comparing centers with different regulation levels. While the differences in quality observed among these three regulatory groups are striking, it is important to note at the onset of this discussion that the results do not demonstrate a causal connection between government regulation and child care quality, only a correlation. It is important to consider that other unexamined factors, such as the quality of program administration, teacher characteristics, or client family characteristics, may have contributed to the patterns we observed.

\section{Global Child Care Quality in Centers with Varying Regulation}

Overall child care quality was highest in licensed, center-based child care centers and lowest in licenseexempt registered ministry centers. This finding is consistent with previous studies that found that in states where stricter licensing standards were required for child care centers, child care quality was generally higher (Phillips et al., 1992; Rigby et al., 2007). While the licensed group was the highest in quality, the quality score for registered ministries, the least regulated group, were surprisingly low. On the ERS global quality scales, a score of a 3 is considered "minimal" quality, and any score below 3 is 
considered inadequate quality (Harms et al., 2005). The mean global quality scores in both preschool classrooms and infant-toddler classrooms within registered ministries were below 3 and thus considered by the authors of the quality scales to be inadequate to support the needs of young children.

\section{- Preschool classrooms}

The global quality mean in preschool rooms was significantly lower in the registered ministry centers than in the other two regulated child care groups. Registered ministry preschool classrooms also scored significantly lower than licensed centers in all of the ERS subscales. Registered ministries' preschool classrooms were found to have inadequate $(<3)$ quality scores in 5 of the 7 sub-scales: space and furnishing, personal care, language, activities, and program structure. Many programs did not have enough physical materials for play and learning to score in the good quality range. As a result, many of the registered ministries cannot be considered to offer developmentally appropriate opportunities, as defined by current best practice recommendations and research findings.

\section{- Infant classrooms}

The lowest score possible on the ITERS- $R$ is a 1 . Some infant-toddler rooms in the registered ministry group scored a mean of 1 in multiple subscales including: personal care, language, activities, interaction and program structure. The mean score for the personal care sub-scale which includes basic health and safety practices in all the infant-toddler classrooms in the registered ministries group was only 1.73 . Over $66 \%$ of infant/toddler environments in the unlicensed registered ministries observed had more than 4 hazards that could result in serious injury under the item, safety practices, resulting in a score of 1 , or "inadequate." This means that the infant-toddler classrooms in non-VCP registered ministries did not provide for the health and safety of the youngest and most vulnerable children. These hazards are allowed to exist because there are no governmental regulations to prohibit them.

\section{Teacher-Child Interaction Differences \\ -Preschool classrooms}

Teacher-child interaction has been shown in previous research to be the most important aspect of quality that affects children's outcomes. The results of this study show that unlicensed registered child care ministry centers had the lowest levels of positive interactions and the highest level of negative interactions in preschool classrooms among the three groups observed.

Scores for punitiveness, detachment and permissiveness were lowest in VCP registered ministries and highest in non-VCP registered ministries. This 
finding is consistent with existing literature that shows that caregivers in states where there is stricter adherence to regulation are less harsh and more sensitive than caregivers in states that have lax adherence to regulation (Phillips et al., 1992). The licensed centers' mean punitive and detachment interaction levels in this study were between the two registered ministry groups, and not significantly different. However, licensed centers were similar to the $\mathrm{VCP}$ registered ministries in being significantly less permissive that the non-VCP registered ministries. This is likely because there was more structure and more explicit expectations by the teachers in the licensed centers and VCP registered ministries than in the non-VCP registered ministries. In the non-VCP ministries, caregivers were likely to sit back and not engage with children, until something happened that required intervention, and the response was typically to punish the children involved or use other harsh methods of discipline.

In general the highest quality teacher-child interactions in preschool classrooms were found in the VCP registered ministries. The VCP certification is a voluntary program that churches may choose to implement to improve the health and safety characteristics of the child care. Most VCP ministries have completed the state government criteria for the Voluntary Certification Program (VCP) within the last two years and have become a part of the state's voluntary child care quality rating and improvement system (QRIS). While the data do not allow conclusions about causal factors, it is possible that the administrators of these voluntarilyregulated programs have set goals to improve the quality of their programs, which could result in more positive teacher-child interactions. While the VCP ministries did have the most positive and least negative teacherchild interactions, the Voluntary Certification Program is not a cure all, this does not logically lead to a recommendation of a VCP system, rather than state licensing, for all church-affiliated child care programs. First, teacher-child interaction scores of the VCP classrooms were not high in an absolute sense, even though they had the highest group mean in this sample. Thus, there is room for improvement in interaction quality in all of the groups of church-affiliated centers we observed. Second, the health and safety standards required for $\mathrm{VCP}$ are an improvement when compared with virtually no regulation, but other factors associated with the voluntary nature of the VCP program may have resulted in the teacher-child interaction results displayed in this study. VCP directors likely deliberately chose to take steps to improve the quality of their programs, leading to more positive interactions by classroom teachers with preschool-aged 
children in these child care programs.

\section{- Infant classrooms}

The only statistically significant difference in teacher-child interactions among the three types of infant classrooms was found in the punitive sub-scale. Observed teacher-child punitive interactions were highest in the registered ministries, the centers with the lowest level of government regulation. Examples of punitive teacher-child interactions include teachers being critical when an infant or toddler is crying, taking away or withholding food or a bottle as a punishment, and confining infants and toddlers as a means of controlling their behavior. This finding is similar to those of previous studies that revealed harsher teacher-child interactions were most common in programs where regulation standards were lowest (Phillips et al., 1992; Phillips et al., 2000; Phillipsen et al., 1997). These types of interactions are stressful for young children and can have negative developmental consequences for the child (Smith \& Brooks-Gunn, 1997).

\section{Limitations}

In addition to the limitations of a correlational, group comparison design discussed above, there were additional limitations in this study. The small sample size in this study limited statistical power. More reliable and significant results may have been found with a larger sample size. The refusal rates of the programs of programs invited to participate, especially the unlicensed non-VCP ministry centers (45 refusals) undoubtedly reduced the representativeness of the sample. While we cannot be sure, it is likely that the programs that refused from this leastregulated group were of even lower quality than those that did participate in the research. In that case, given a representative sample of leastregulated centers, the differences in quality may have been even greater.

The quality measures used in this study, while validated in many other studies, may not have provided the most comprehensive description of quality for this sample. The ERS global quality scales were difficult to use in some of the centers in the unlicensed registered ministry groups, because the children didn't remain in their classrooms, where the scales are designed to be used. Due to a "community philosophy" espoused in many child care ministries, groups of children sometimes combined and used multiple rooms throughout the day. Also the range of the scores in ERS measures sometimes did not go low enough to accurately describe the poor quality found in license-exempt centers. An example of this was that under safety practices, if four or more hazards that could result in injury to a child are observed, the score for that item is 1 . However, if the classroom or outdoor 
play area had over ten hazards that could result in injury or even death, this undoubtedly presented an even greater risk for children, but this higher level of risk is not specifically reflected in the ERS score, which could not go lower than 1. Examples of safety hazards observed and documented within the reach of preschoolers and toddlers, but not listed in the ERS, included: industrial chemical waste in open containers, rusty sharp pieces of metal, animal carcasses, and discarded broken toilets.

A final limitation of this study is that we did not measure associations among regulation level, quality, and child outcomes. More research is needed to examine quality and child outcomes in church-sponsored, unlicensed child care, and other forms of unregulated child care. Additional research is also needed to investigate what specific regulatable structural characteristics, such as teacher education level or specialty, will have the greatest impact on improving child care quality and child outcomes, in both churchsponsored and non-secular child care centers.

\section{Implications for Policy and Research}

As shown in this and other studies, governmental regulation level is associated with child care quality. Even if regulation standards address only basic health and safety issues, such rules are associated with improvements in the daily conditions for young children in child care. When state and federal governments legislate health and safety standards for institutions or industries, the implication is that persons' well-being is of some value, or holds an importance to society. For example, public education of school age children is important to society, and we have many standards and regulations to help guide the education of these children. Yet for the youngest children in the U.S., those who are most vulnerable, there are no quality standards in many of the child care settings where they spend most of their waking hours. This study found that for young children in church-sponsored child care in the state of Indiana, unregulated environments where they spend their days are inadequate in quality to support their development.

There are many questions still unanswered. For example, how many license-exempt child care programs exist nationwide, and how many young children are enrolled in those programs. It is important that researchers not simply assume that all child care centers are licensed by the local or federal government, because regulatory exemptions may be present in many localities. Therefore regulation level or license-exempt status should be considered an important variable in future research focused on child care quality. If researchers are able to identify and assess license-exempt 
programs in their child care quality analyses, accounting for this important characteristic will reduce measurement error, and effect sizes may increase for other variables that enable examination of relationships between child care quality and child outcomes. Licenseexempt status should be more transparent for both researchers and families, and policy makers should consider carefully whether all child care centers need to be regulated by governmental authorities to ensure safe and developmentally-supportive environments for all young children.

\section{References}

Arnett, J. (1989). Caregivers in day-care centers: Does training matter? Journal of Applied Developmental Psychology, 10, 541-552. doi:10.1016/2F0193-3973(89)90026-9

Belsky, J., Vandel, D. L., Burchinal, M., Clarke-Stewart, K. A., McCartney, A., \& Owen, M. T. (2007). Are there long term effect of early child care? Child Development, 72, 681-01. doi: 10.1111/j.1467-8642.2007.01021.x.

Bisceglia, R., Perlman, M., Schaak, D., \& Jenkins, J. (2009). Examining the psychometric properties of the InfantToddler Environment Rating ScalesRevised Edition in a high-stakes context. Early Childhood Research Quarterly, 24, 121-132. doi:10.1016/ j.ecresq.2009.02.001.

Burke, C., Fossett, J., \& Gais, T. (2004). Funding faith-based social services in a time of fiscal pressure. Washington, D.C.: The Roundtable on Religion and Social Welfare Policy.

Cassidy, D.J., Hestenes, L. L., Hegde, A., Hestenes, S., \& Mims, S. (2005). Measurement of quality in preschool child care classrooms: An exploratory and confirmatory factor analysis of the early childhood environment rating scale revised. Early Childhood Research Quarterly, 20, 345-360. doi:10.1016/ j.ecresq.2005.07.005.

Elicker, J., Langill, C., Ruprecht, K., \& Lewsader, J. (2010). Paths to Quality Evaluation General Parent Survey Report, Purdue University, West Lafayette, Indiana.

Elicker, J., Clawson, C., Hong, S., Kim, T., Evangelou, D., \& Kontos, S. J. (2005). Child care for working poor families: Child development and parent employment outcomes. Lafayette, IN: Purdue University.

Family and Social Services Administration. (2009). Indiana Administrative Code, Rule 4.7 Child Care Centers; Licensing. Retrieved from http://www.ingov/fssa/ files/ Rule4.7.pdf.

Family and Social Services Administration. (2011, November). Voluntary Certification Program Standards. Retrieved from http://www.in.gov/fssa/files/VCP_S tandards.pdf.

Family and Social Services Administration. (2013, January). Child Care Licensing Unit Monthly/YTD Report. Division of Family and Children, Bureau of Child Development. Retrieved from http://www.ingov/fssa/files/Monthl yYTDReport.pdf. 
Family and Social Services Administration. (2013). CCDF Fact Sheet Indiana: Statewide summary voucher and contract centers programs. Retrieved from http://www.in.gov/fssa/files/FactSh eet.pdf.

Geoffroy, M., Cote, S. M., Gigue`re, C., Dionne, G., Zelazo, P. D., Tremblay, R. E., \& Seguin, J. R. (2010). Closing the gap in academic readiness and achievement: The role of early childcare. Journal of Child Psychology and Psychiatry, 51, 1359- 1367. doi:10.1111/j.1469-7610.2010.02316.x.

Goelman, H., Forer, B., Kershaw, P., Doherty, G., Leno, D., \& LaGrange, A. (2006). Towards a predictive model of quality in Canadian child care centers. Early Childhood Research Quarterly, 21, 280-295. doi: 10.1016/j.ecresq.2006.07.005.

Gormley, W. T. (1995). Everybody's children: Child care as a public problem. Washington, D.C.: The Brookings Institution.

Harms, T., Cryer, D., \& Clifford, R. (1998). Early childhood environmental rating scale: Revised edition. New York: Teachers College Press.

Harms, T., Cryer, D., \& Clifford, R. (2003). Infant toddler environmental rating scale: Revised edition. New York: Teachers College Press.

Henriques, D. B. (2006). Religion trumps regulation as legal exemptions grow. New York Times, October 8.

Human Development Study of Early Child Care and Youth Development. Journal of Applied Developmental Psychology, 28, 390-410. doi:10.1016/j.appdev.2007.06.003.

Kosmin, B.A. \& Keysar, A. (2009). American religious identification survey. (ARIS 2008). Hartford, CT: Trinity College. (www.americanreligionsurvey-aris.org) Mashburn, A. J., Pianta, R. C., Hamre, B. K., Downer, J. T., Barbarian, O. A., Bryant, D., Burchinal, M. R., Early, D., \& Howes, C. (2008). Measures of classroom quality in prekindergarten and children's development of academic, language, and social skills. Child Development, 79(3), 732-749.

National Association for Regulatory Administration and the National Child Care Information and Technical Assistance Center. (2010). The 2008 child care licensing study: Final report. Retrieved from http://www.nara. affiniscape.com/ displaycommon.cfm? an=1\&subarticlenbr=104

National Child Care Resource and Referral Association. (2012). License-exempt child care. Retrieved from http://www.naccrra. org/sites/default/files/default_site_p ages/2012/ccgb_license_exempt_jan20 12.pdf.

NICHD Early Child Care Research Network (1996). Characteristics of infant child care: Factors contributing to positive caregiving. Early Childhood Research Quarterly,11, 269-306.

NICHD Early Child Care Research Network (1999). Child outcomes when child care center classes meet recommended standards for quality. American Journal of Public Health, 89, 1072-1077.

Phillips, D., A., Howes, C., \& Whitebook, M. (1992). The social policy context of child care: Effects on quality. American Journal of Community Psychology, 20, 25- 
51. doi: 10.1007/BF00942180.

Phillips, D., Mekos, D., Scarr, S., McCartney, K., \& Abbott-Shim, M. (2000). Within and beyond the classroom door: Assessing quality in child care centers. Early Childhood Research Quarterly, 15, 475-496. doi:10.1016/S0885-2006(01)00077-1.

Phillipsen, L. C., Burchinal, M. R., Howes, C., \& Cryer, D. (1997). The prediction of process quality from structural features of child care. Early Childhood Research Quarterly, 12, 281-303. doi: 10.1016/S0885-2006(97)90004-1.

Pinto, A. I., Pessanha, M., \& Aguiar, C. (2013). Effects of home environment and center-based child care quality on children's language, communication, and literacy outcomes. Early Childhood Research Quarterly, 28, 94-101. doi: 10.1016/j.ecresq.2012.07.001.

Rigby, E., Ryan, R. M., \& Brooks-Gunn, J. (2007). Child care quality in different state policy contexts. Journal of Policy Analysis and Management, 26, 887-907. doi:10.1002/pam.20290.

Rohacek, M., Adams, G., \& Snyder, K. (2008). Child care centers, child care vouchers, and faith-based organizations.
Washington, D. C.: The Urban Institute. Slutz, T. (2000). Congregations and child care. Responsive Communities, 1(8), 1-5. Retrieved from http//www.polis.iupui. edu/ruc.

Smith, J.R. \& Brooks-Gunn, J. (1997). Correlates and consequences of harsh discipline for young children. Archives of Pediatrics \& Adolescent Medicine, 151(8), 777-786. doi:10.1001/archpedi.1997. 02170450027004 .

Sosinsky, L. S., Lord, H., \& Zigler, E. (2007). For-profit/nonprofit differences in center-based child care quality: Results from the National Institute of Child Health and

Stanziola, J., \& Schmitz, T. (2003). The impact of devolution on organizational effectiveness: An exploratory case study of faith-based child care. The Qualitative Report, 8, 655-675.

Vandell, D. L., Belskey, J., Burchinal, M., Steinburg, L., \& Vandergrift, N. (2010). Do effects of early child care extend to age 15 years? Results from NICHD study of early child care and youth development. Child Development, 81, 737-756. doi: 10.1111/j1467-8624.2010.01431.x 